\title{
Neuroimmune interaction between multiple sclerosis and inflammatory bowel disease
}

\author{
Basilio Vagner Ramirez ${ }^{1}$, Catalina Rojas Acosta ${ }^{2}$ \\ ${ }^{1}$ Medicarte, Multiple Sclerosis Program, Medellin, Colombia \\ ${ }^{2}$ Novartis Medical Science Liason, Bogota, Colombia \\ Email: Basilio_vagner@hotmail.com, catalina.rojas_acosta@novartis.com
}

Received 25 June 2013; revised 28 July 2013; accepted 15 August 2013

Copyright (C) 2013 Basilio Vagner Ramirez, Catalina Rojas Acosta. This is an open access article distributed under the Creative Commons Attribution License, which permits unrestricted use, distribution, and reproduction in any medium, provided the original work is properly cited.

\begin{abstract}
Inflammatory bowel disease is represented by two well-known diseases: ulcerative colitis and Crohn's disease. These two entities have been found on multiple sclerosis patients. Although the location and clinical manifestations of these diseases are very different, their immune response patterns present many similarities. This article examines the immune pathology of inflammatory bowel disease and its relationship to the immunological behavior of multiple sclerosis.
\end{abstract}

Keywords: MS; IBD; Immunological Relationship; HLA

\section{INTRODUCTION}

Inflammatory Bowel Diseases (IBD) such as ulcerative colitis (UC) and Crohn's disease (CD) are characterized by chronic evolution affecting the gastrointestinal tract, with diverse patterns as well as extra-intestinal manifesttations [1].

$\mathrm{UC}$ affects exclusively the Colon and the rectum. Its main symptoms are rectorrhagia diarrhea and abdominal pain. In severe cases dehydration, fever, anemia and weight loss are also found. It usually comes with abdominal distention on the colic zone and associated tenderness to palpation $[2,3]$.

In case of $\mathrm{CD}$ almost any part of the gastrointestinal tract may be affected. Thus its clinical manifestations depend on the place of the lesion. The most frequent symptoms are fever, diarrhea, abdominal pain, fatigue, and weight loss. Rectal bleeding is less frequent than in case of ulcerative colitis [4]. Fistulas and their connection to diverse organs of the abdominal and thoracic cavities as well as bacterial overgrowth with formation of abscesses when these fistulas occlude are very common
[5].

Multiple sclerosis patients have been reported both for UC and CD [6-8]. Multiple sclerosis (MS) is a chronic, inflammatory and degenerative disease of the white matter of the central nervous system $[9,10]$. Its clinical manifestations depend on the location of the lesions, and its way of expression varies in relation to diverse immune conditions [11]. This article describes some IBD and MS immunologic mechanisms as well as its possible immunologic associations.

\section{ULCERATIVE COLITIS AND CROHN'S DISEASE IMMUNOPATHOLOGY}

The immunologic mechanism of the disease is still unknown, but for IBD, the more prevalent theory so far for IBD the prevailing theory is genetic susceptibility to the host and exposure to some environmental factor unleashing the inflammatory reaction against the intestine [12]. According to the theory, asides from intestinal microbial antigens and some environmental unleashing activator, genetic susceptibility, and immunologic behavior are key factors to the behavior of these pathologies [13].

\section{GENETIC SUSCEPTIBILITY TO INFLAMMATORY BOWEL DISEASE}

Six among the genes studied were identified as possibly related to the susceptibility to the host. The ones identified for CD are: CARD15, SLC22A4, SLC22A5, DLG5, $P P A R G$, and for $\mathrm{UC}$ is $M D R 1$.

\subsection{Member 15 of the Family with Caspases Recruitment Domain}

(CARD15) o NOD2: Some mutations of this gen may have a Leucine rich repeat width recognizes bacteria 
peptidoglycan, this recognition complex acknowledges the $\mathrm{k} \beta$ nuclear $(\mathrm{NFk} \beta)$, which unleashes the transcription of inflammatory molecules which take part on the defense of counter pathogens [14].

\subsection{Solute Transporting Proteins (SLC22A4ySLC22A5)}

These proteins with mutations in their promoter and in their transcribing region affect carnitine transportation at the intestinal epithelium [15].

\subsection{Gen Homologous to Discs on Drosophila (DLG5)}

Structural protein protecting the integrity of the epithetlium, altered on $\mathrm{CD}[16]$.

\subsection{Peroxisome Proliferator Activated Receptor Gamma (PPARG)}

Nuclear receptor which inhibits NFkB, reduced UC expression [17].

\subsection{Multidrug Resistance Gen (MDR1)}

Protein in charge of transporting cellular xenobiotics, variant 1 has been related to $\mathrm{UC}$ and $\mathrm{CD}$ [18].

\section{INFLAMMATORY BEHAVIOR ON INFLAMMATORY BOWEL DISEASES (ULCERATIVE COLITIS AND CROHN'S DISEASE)}

The IBDs present similar innate immunity. The response is characterized by the presence of activated macrophages and neutrophils, as well as T and B cells. Although expression of proinflammatory interleukins riseson both IBD sub-types, it is higher with Crohn's Disease. Interleukins rising expression on both pathologies are: IL-1 $\beta$, TNF, IL-6, IL-8a and IL-18. The ones rising exclusively with CD through TH1 and TH17 cells are: IL-12, IL-23, IL-27, IFN $\gamma$, IL-17 and IL-21; and specifically expressed with UC are: IL-5 and IL-13 [13].

On both subtypes of pathologies a marked increase with respect to adhesion molecules is evident, the expression of molecular adhesion cell 1(ICAM1) rises on these immunologic cascades as it acts in fastening and transferring immune cells to the epithelium [19].

Initial recognition and bonding of epithelial cells and bacteria takes place through TLR receptors, which are normally found in low concentrations in the epithelium cells, and increase their expression in the presence of any immunogenic reaction against antigens. NFkB transcripttion is activated when the TLR receptor connects to its corresponding adjuvant. The NFkB factoris the main activator of the immunologic cascade on IBD, since after its initial expression, molecules such as: IL- $1 \beta$, TNF, IL-6, IL-8, ICAM1 and adhesion molecules like CD40, CD80, CD 86 and ICOS (inducible T cells co-stimulator). Additionally it has been seen on trials with mice that NFkB attenuation, decreases experimental colitis [20].

Unlike innate immunity, acquired immunity on Crohn's Disease and on Ulcerative Colitis shows different patterns. On Crohn's Disease TH1 cells dominate the cascade. In this response, cells presenting antigens produce IL-12, which induces IFN- $\gamma$ into activating TH1. Production of TH17 in Crohn's Disease is regulated by the production of IL-17, which in turn is stimulated by IL-6, TGFB and by IL-23 [21].

In ulcerative colitis, the immunological pattern is characterized mainly by TH2 cells mediated by natural killer cells (NK) which produce IL-13. Natural killer cells in this immunologic pattern are produced by presentation of lipids and not by antigenic proteins. Activation of $\mathrm{T}$ cells takes place normally at the lymph nodes and is characterized by the secretion of IL-6, IL-12, IL-23, IL-10 or TGF $\beta$.

\section{DEGENERATIVE AND INFLAMMATORY BEHAVIOR OF MULTIPLE SCLEROSIS}

As experimental autoimmune encephalomyelitis (EAE) studies have shown Multiple Sclerosis is a TH1 CD4+ cells mediated disease, the immunologic cascade starts with the activation of the innate immune regulatory response to T cells; the presentation of the antigen between $\mathrm{T}$ cells and antigen presenter cells (APC) allows clonal expansion. $\mathrm{T}$ cell recognizes the antigens which join its receptor (TCR); this mediated by the intervention of the major histocompatibility complex (MHC), which is expressed on the surface of the antigens presenting cells APC).

TCR bonding by the MHC-antigen complex, with help from co-stimulating cells, unleashes a $\mathrm{T}$ cells stimulating signal [22].

The characteristics of the antigen that is presented and the co-stimulating production of cytokines within the node polarize the cellular differentiation to $\mathrm{CD} 4+\mathrm{T}$ helper 1 (TH1), TH2, TH17or regulating T cells (TReg) andcytotoxic CD8+. After their clonal expansion these cells travel through leptomeningeal arteries crossing the hematoencephalic barrier (HEB), intervene a complex of cellular adhesion molecules, intercellular adhesion molecules I (ICAM-1) and vascular cellular adherence molecules 1 (VCAM1).

Metallo proteinases like MMP-9 and MMP-2 which digest the fibronectin and the collagen of the basal membrane also take part on HEB disruption [23]. When T cells (Th1, Th17, CD8+ cytotoxic and B cells) cross the HEB and arrive at the central nervous system (CNS), 
they are reactivated, clonally expanded and differentiated by an autoantigen presented by the dendritic cells [24].

Together, astrocytes and activated microglia increase inflammatory cytokines, oxygen reactive species, glutamate excitotoxicity and production of antibodies against themyelin protein [25].

\section{IMMUNOLOGICAL RELATIONSHIP BETWEEN INFLAMMATORY BOWEL DISEASE AND MULTIPLE SCLEROSIS}

The association between these two entities has been reported in multiple instances. It was first described in 1982 [26-28]. With prevalence of $0.5 \%-1.0 \%$ between MS and IBD, reason why its relationship is not considered a random phenomenon [29]. Additionally they share common epidemiologic elements such as age of appearance, clinical course, and geographic distribution [30].

The common patho physiological mechanism between these two entities is still unknown, but it seems to implicate genetic, immunologic, and environmental factors; among the genetic factors, diverse HLA alleles relate to the development of autoimmune diseases [31]. A nonHLA haplotype, IBD5 is currently considered an interacttion risk [32].

Two factors may be considered of great interest in the immune context: the first one is the phenomenon of antigenic mimicry with polyclonal lymphocytes activation. For MS there are several related entities; among them the human herpesvirus 6 (HHV-6) and the Epstein-Barr virus (EBV) $[33,34]$ present a strong relationship to the development of MS, as well as the human herpesvirus type 1 (HSV-1) the varicella zoster virus (VZV or HSV-3), or the influenza virus. One related entity among bacteriais Chlamydia pneumoniae (Cpn) [35,36]. Molecular mimicry implies reactivity of $\mathrm{T}$ and $\mathrm{B}$ cells, whether with peptides or with antigenic determinants shared by infections and by autoantigens [37].

Specific myelin proteins autoreactivelymphocytes, IFN- $\gamma$ secretion by $\mathrm{T}$ helper 1 cells ("Th1"), production of IL-17, and Th17 cells activation are developed peripherally with subsequent migration to the central nervous system $[38,39]$. There are multiple proteins related to the immune mimicry phenomenon, and most significant among them:

- Proteolipid Protein (PLP) [40]

- Myelin Associated Glycoprotein (MAG) [41]

- $\mathrm{S} 100 \beta$ Protein [42]

- Myelin Oligodendrocyte Glycoprotein (MOG) [43]

- Associated Oligodendrocyte Basic Protein (MOBP) [44]

- Oligodendrocyte Specific Glycoprotein (OSP) [45]

- Myelin Base Protein (MBP) [46]

The second relevant factor is immunomodulation mediated by parasites by their interaction with $\mathrm{B}$ and $\mathrm{T}$ cells, inducing a response modified by Th2, with a phenomenon of dendritic cells tolerance to antigens [47]. ES-62 is an Acanthonema vitae glycoprotein, with an immunomodulating effect, which inhibits IL-12 and IFN $\gamma$ secretion, IL10 proliferation and production, and inhibits dendritic cells maturation [48]. Helminthes infections may alter TLR4 expression on T cells, and in turn Schistosome-derive dlysophosphatidic serine may affect TLR2 activity, promoting dendritic cells differentiation which induce regulating T cells with IL10 anti inflammatoryinterlokins secretion [49,50]. Other example are Schistosomamansoni eggs soluble fractions altering the TLR ligand, inducing dendritic cells activation, and enzymatic activity of helminthes derived products, whose function to maintain the infectious process is capable of modulating the innate system response [51].

Other interesting and common element reported for both pathologies is vitamin D deficiency [52].

\section{CONCLUSION}

The incidence of patients with cases of inflammatory bowel disease whether Crohn's disease or ulcerative colitis and multiple sclerosis has been increased during the past 50 years. Both pathologies share epidemiologic characteristics such as age of occurrence, the clinical course and geographic dependent prevalence and incidence. Shared cellular factors are IBD5 protein, antigenic mimicry with diverse human proteins and with some bacteria, as well as parasite mediated immunomodulation.

\section{REFERENCES}

[1] Danzi, J.T. (1988) Extraintestinal manifestations of idiopathic inflammatory bowel disease. Archives of Internal Medicine, 148, 297-302.

http://dx.doi.org/10.1001/archinte.1988.00380020041008

[2] Stange, E.F., Travis, S.P.L., Vermeire, S., et al. (2008) European evidence-based consensus on the diagnosis and management of ulcerative colitis: Definitions and diagnosis. Journal of Crohn's and Colitis, 2, 1-23.

[3] Dendrinos, K., Cerda, S. and Farraye, F.A. (2008) The "cecal patch" in patients with ulcerative colitis. Gastrointestinal Endoscopy, 68, 1006-1007. http://dx.doi.org/10.1016/j.gie.2008.04.003

[4] Baumgart, D.C. and Sandborn, W.J. (2012) Crohn's disease. The Lancet, 380, 1590-1605.

[5] Greenstein, A.J., Mann, D., Heimann, T., Sachar, D.B., Lachman, P. and Aufses Jr., A.H. (1987) Spontaneous free perforation and perforated abscess in 30 patients with Crohn's disease. Annals of Surgery, 205, 72-76. http://dx.doi.org/10.1097/00000658-198701000-00013

[6] Buccino, G.P., Corrente, G. and Visintini, D. (1994) Crohn's disease and multiple sclerosis: A single case report. The Italian Journal of Neurological Sciences, 15, 
303-306. http://dx.doi.org/10.1007/BF02339241

[7] Pokorny, C.S., Beran, R.G. and Pokorny, M.J. (2007) Association between ulcerative colitis and multiple sclerosis. Internal Medicine Journal, 37, 721-724. http://dx.doi.org/10.1111/j.1445-5994.2007.01452.x

[8] Schott, E., Paul, F., Wuerfel, J.T., Zipp, F., Rudolph, B., Wiedenmann, B. and Baumgart, D.C. (2007) Development of ulcerative colitis in a patient with multiple sclerosis following treatment with interferon beta 1a. World Journal of Gastroenterology, 13, 3638-3640.

[9] Hauser, S.L. and Oksenberg, J.R. (2006) The neurobiology of multiple sclerosis: Genes, inflammation, and neurodegeneration. Neuron, 52, 61-76. http://dx.doi.org/10.1016/j.neuron.2006.09.011

[10] Barnett, M.H. and Prineas, J.W. (2004) Relapsing and remitting multiple sclerosis: Pathology of the newly forming lesion. Annals of Neurology, 55, 458-468. http://dx.doi.org/10.1002/ana.20016

[11] Lublin, F.D. and Reingold, S.C. (1996) Defining the clinical course of multiple sclerosis: results of an international survey. National Multiple Sclerosis Society (USA) Advisory Committee on Clinical Trials of New Agents in Multiple Sclerosis. Neurology, 46, 907-911. http://dx.doi.org/10.1212/WNL.46.4.907

[12] Pierik, M., Yang, H., Barmada, M.M., et al. (2006) The BID international gebetics consortium provides further evidence for linkage to IBD4 and shows gene-environment interaction. Inflammatory Bowel Diseases, 11, 1-7. http://dx.doi.org/10.1097/00054725-200501000-00001

[13] Balfour, R. (2006) Mechanisms of disease: Pathogenesis of Crohn's disease and ulcerative colitis. Nature Clinical Practice Gastroenterology \& Hepatology, 3, 390-407. http://dx.doi.org/10.1038/ncpgasthep0528

[14] Cario, E. (2005) Bacterial interactions with cells of the intestinal mucosa: Toll-like receptors and NOD2. Gut, 54, 1182-1193. http://dx.doi.org/10.1136/gut.2004.062794

[15] Noble, C.L., et al. (2005) The contribution of OCTN1/2 variants within the IBD5 locus to disease susceptibility and severity in Crohn's disease. Gastroenterology, 129, 1854-1864. http://dx.doi.org/10.1053/j.gastro.2005.09.025

[16] Stoll, M., et al. (2004) Genetic variation in DLG5 is associated with inflammatory bowel disease. Nature Genetics, 36, 476-480. http://dx.doi.org/10.1038/ng1345

[17] Dubuquoy, L., et al. (2003) Impaired expression of peroxisome proliferator-activated receptor $\gamma$ in ulcerative colitis. Gastroenterology, 124, 1265-1276. http://dx.doi.org/10.1016/S0016-5085(03)00271-3

[18] Brant, S.R., et al. (2003) MDR1 Ala893 polymorphism is associated with inflammatory bowel disease. The American Journal of Human Genetics, 73, 1282-1292. http://dx.doi.org/10.1086/379927

[19] Reaves, T.A., et al. (2005) Neutrophil transepithelial migration: Role of toll-like receptors in mucosal inflamemation. Memórias do Instituto Oswaldo Cruz, 100, 191-198. http://dx.doi.org/10.1590/S0074-02762005000900033

[20] Neurath, M.F., et al. (1996) Local administration of an- tisense phosphorothioate oligonucleotides to the p65 subunit of NF- $\mathrm{\kappa B}$ abrogates established experimental colitis in mice. Nature Medicine, 2, 998-1004. http://dx.doi.org/10.1038/nm0996-998

[21] Schmidt, C., et al. (2005) Expression of interleukin-12related cytokine transcripts in inflammatory bowel disease: Elevated interleukin-23p19 and interleukin-27p28 in Crohn's disease but not in ulcerative colitis. Inflammatory Bowel Diseases, 11, 16-23.

http://dx.doi.org/10.1097/00054725-200501000-00003

[22] Multiple Sclerosis International Federation (2008) Atlas of MS database. Multiple Sclerosis International Federation Website. http://www.atlasofms.org/ index.aspx

[23] Kieseier, B.C., Seifert, T., Giovannoni, G., et al. (1999) Matrix metalloproteinases in inflammatory demyelination: Targets for treatment. Neurology, 53, 20-25.

http://dx.doi.org/10.1212/WNL.53.1.20

[24] Compston, A. and Coles, A. (2002) Multiple sclerosis. Lancet, 359, 1221-1231. http://dx.doi.org/10.1016/S0140-6736(02)08220-X

[25] Kasper, L.H. and Shoemaker, J. (2010) Multiple sclerosis immunology: The healthy immune system vs the MS immune system. Neurology, 74, S2-S8. http://dx.doi.org/10.1212/WNL.0b013e3181c97c8f

[26] Scheid, R. and Teich, N. (2007) Neurologic manifestations of ulcerative colitis. European Journal of Neurology, 14, 483-493. http://dx.doi.org/10.1111/j.1468-1331.2007.01718.x

[27] Purrmann, J., Arendt, G., Cleveland, S., et al. (1992) Association of Crohn's disease and multiple sclerosis. Is there a common background? Journal of Clinical Gastroenterology, 14, 43-46. http://dx.doi.org/10.1097/00004836-199201000-00011

[28] Rang, E.H., Brooke, B.N. and Hermon-Taylor, J. (1982) Association of ulcerative colitis and multiple sclerosis. Lancet, 2, 555. http://dx.doi.org/10.1016/S0140-6736(82)90629-8

[29] Kimura, K., Hunter, S.F., Thollander, M.S., Loftus Jr., E.V., Melton III, L.J., O'Brien, P.C., et al. (2000) Concurrence of inflammatory bowel disease and multiple sclerosis. Mayo Clinic Proceedings, 75, 802-806. http://dx.doi.org/10.4065/75.8.802

[30] Green, C., Elliott, L., Beaudoin, C., et al. (2006) A population-based ecologic study of inflammatory bowel disease: Searching for etiologic clues. American Journal of Epidemiology, 164, 615-623. http://dx.doi.org/10.1093/aje/kwj260

[31] Lettre, G. and Rioux, J.D. (2008) Autoimmune diseases: Insights from genome-wide association studies. Human Molecular Genetics, 17, R116-R121. http://dx.doi.org/10.1093/hmg/ddn246

[32] De Jager, P.L., Graham, R., Farwell, L., Sawcer, S., Richardson, A., Behrens, T.W., Compston, A., Hafler, D.A., Kere, J., Vyse, T.J. and Rioux, J.D. (2006) The role of inflammatory bowel disease susceptibility loci in multiple sclerosis and systemic lupus erythematosus. Genes \& Immunity, 7, 327-334.

http://dx.doi.org/10.1038/sj.gene.6364303 
[33] Soldan, S.S., Leist, T.P., Juhng, K.N., Mc-Farland, H.F. and Jacobson, S. (2000) Increased lymphoproliferative response to human herpesvirus type 6A variant in multiple sclerosis patients. Annals of Neurology, 47, 306-313. http://dx.doi.org/10.1002/1531-8249(200003)47:3<306:: AID-ANA5>3.0.CO;2-A

[34] Wandinger, K.P., Jabs, W., Siekhaus, A., Bubel, S., Trillenberg, P., et al. (2000) Association between clinical disease activity and Epstein-Barr virus reactivation in MS. Neurology, 55, 178-184. http://dx.doi.org/10.1212/WNL.55.2.178

[35] Sriram, S., Mitchell, W. and Stratton, C. (1998) Multiple sclerosis associated with Chlamydia pneumoniae infection of the CNS. Neurology, 50, 571-572. http://dx.doi.org/10.1212/WNL.50.2.571

[36] Pucci, E., Taus, C., Cartechini, E., Morelli, M., Giuliani, G., et al. (2000) Lack of Chlamydia infection of the central nervous system in multiple sclerosis. Annals of $\mathrm{Neu}$ rology, 48, 399-400. http://dx.doi.org/10.1002/1531-8249(200009)48:3<399:: AID-ANA20 $>3.0 . \mathrm{CO} ; 2-\mathrm{T}$

[37] Tejada-Simon, M.V., Zang, Y.C.Q., Hong, J., Rivera, V.M. and Zhang, J.W.Z. (2003) Crossreactivity with myelin basic protein and human herpesvirus- 6 in multiple sclerosis. Annals of Neurology, 53, 189-197. http://dx.doi.org/10.1002/ana.10425

[38] Baker, D., O’Neill, J.K. and Turk, J.L. (1991) Cytokines in the central nervous system of mice during chronic relapsing experimental allergic encephalomyelitis. Cellular Immunology, 134, 505-510. http://dx.doi.org/10.1016/0008-8749(91)90321-2

[39] Sospedra, M. and Martin, R. (2005) Immunology of multiple sclerosis. Annual Review of Immunology, 23, 683747. http://dx.doi.org/10.1146/annurev.immunol.23.021704.11 $\underline{5707}$

[40] Bielekova, B., Sung, M.H., Kadom, N., Simon, R., McFarland, H. and Martin, R. (2004) Expansion and functional relevance of highavidity myelin-specific CD4+ T cells in multiple sclerosis. The Journal of Immunology, 172, 3893-3904.

[41] Morris-Downes, M.M., McCormack, K., Baker, D., Sivaprasad, D., Natkunarajah, J. and Amor, S. (2002) Encephalitogenic and immunogenic potential of myelin-associated glycoprotein (MAG), oligodendrocytespecific glycoprotein (OSP) and 2',3'-cyclic nucleotide 3'-phosphodiesterase (CNPase) in $\mathrm{ABH}$ and SJL mice. Journal of Neuroimmunology, 122, 20-33. http://dx.doi.org/10.1016/S0165-5728(01)00460-X

[42] Schmidt, S., Linington, C., Zipp, F., Sotgiu, S., de Waal Malefyt, R., et al. (1997) Multiple sclerosis: Comparison of the human T-cell response to $\mathrm{S} 100 \beta$ and myelin basic protein reveals parallels to rat experimental autoimmune panencephalitis. Brain, 120, 1437-1445. http://dx.doi.org/10.1093/brain/120.8.1437
[43] Bettelli, E., Pagany, M., Weiner, H.L., Linington, C., Sobel, R.A. and Kuchroo, V.K. (2003) Myelinoligodendrocyteglycoproteinspecific $\mathrm{T}$ cell receptor transgenic mice develop spontaneous autoimmune optic neuritis. The Journal of Experimental Medicine, 197, 1073-1081. http://dx.doi.org/10.1084/jem.20021603

[44] Kaye, J.F., Kerlero de Rosbo, N., Mendel, I., Flechter, S., Hoffman, M., et al. (2000) The central nervous sytemspecific myelin oligodendrocytic basic protein (MOBP) is encephalitogenic and a potential target antigen in multiple sclerosis (MS). The Journal of Immunology, 102, 189198. http://dx.doi.org/10.1016/S0165-5728(99)00168-X

[45] Berger, T. and Reindl, M. (2007) Multiple sclerosis: Disease biomarkers as indicated by pathophysiology. Journal of the Neurological Sciences, 259, 21-26.

[46] Ota, K., Matsui, M., Milford, E.L., Mackin, G.A., Weiner, H.L. and Hafler, D.A. (1990) T-cell recognition of an immunodominant myelin basic protein epitope in multiple sclerosis. Nature, 346, 183-187. http://dx.doi.org/10.1038/346183a0

[47] Adalid-Peralta, L., Fragoso, G., Fleury, A. and Sciutto, E. (2011) Mechanisms underlying the induction of regulatory $\mathrm{T}$ cells and its relevance in the adaptive immune response in parasitic infections. International Journal of Biological Sciences, 7, 1412-1426. http://dx.doi.org/10.7150/ijbs.7.1412

[48] Goodridge, H.S., Marshall, F.A., Else, K.J., Houston, K.M., Egan, C., Al-Ryami, L., Liew, F.Y., Harnett, W. and Harnett, M.M. (2005). Immunomodulation via novel use of TLR4 by the filiarial diseases. Immunological Reviews, 227, 248-263.

[49] Ince, M.N., Elliott, D.E., Setiawan, T., Blum, A., Metwali, A., Wang, Y., Urban Jr., J.F. and Weinstock, J.V. (2006) Heligmosomoides polygyrus induces TLR4 on murine mucosal $\mathrm{T}$ cells that produce TGFbeta after lipopolysaccharide stimulation. The Journal of Immunology, 176, 726-729.

[50] Moreels, T.G., Nieuwendijk, R.J., De Man, J.G., De Winter, B.Y., Herman, A.G. and Van Marck, E.A. (2004) Concurrent infection with Schistosomamansoni attenuates inflammation induced changes in colonic morphology, cytokine levels and smooth muscle contractility of trinitrobenzenesulphonic acid induced colitis in rats. Gut, 53, 99-107. http://dx.doi.org/10.1136/gut.53.1.99

[51] Everts, B., Smits, H.H., Hokke, C.H. and Yazdanbakhsh, M. (2010) Helminths and dendritic cells: Sensing and regulating via pattern recognition receptors, Th2 and Treg responses. European Journal of Immunology, 40, 15251537. http://dx.doi.org/10.1002/eji.200940109

[52] Cantorna, M.T. (2006) Vitamin D and its role in immunology: Multiple sclerosis, and inflammatory bowel disease. Progress in Biophysics and Molecular Biology, 92, 60-64.

http://dx.doi.org/10.1016/j.pbiomolbio.2006.02.020 